Article

\title{
Green Restaurant Consumers' Pride and Social Healthy Narcissism Influencing Self-Actualization and Self-Transcendence That Drive Customer Citizenship Behavior
}

\author{
Kumju Hwang ${ }^{1}$, Bora Lee ${ }^{2}$ and Juhee Hahn ${ }^{1, *}$ \\ 1 College of Business and Economics, Chung-Ang University, Seoul 06974, Korea; kumju@cau.ac.kr \\ 2 The Graduate School, Chung-Ang University, Seoul 06974, Korea; boralee92@naver.com \\ * Correspondence: jhan@cau.ac.kr
}

Received: 23 November 2020; Accepted: 7 December 2020; Published: 10 December 2020

\begin{abstract}
This study explored green restaurant consumers' self-actualization and self-transcendence motivations that drive customer citizenship behavior (CCB). A survey of green restaurant consumers was administered, and structural equation modeling (SEM) analysis was performed. The findings indicate the presence of positive associations between pride and self-actualization, and healthy social narcissism and self-transcendence. This study also found a positive relationship between self-actualization and self-transcendence, and they are positively associated with CCB. Interestingly, the findings suggest that green restaurant consumers' pride, self-actualization and CCB path is more dominant path vis-à-vis the path from healthy social narcissism mediated by self-transcendence to CCB.
\end{abstract}

Keywords: green restaurant consumers' pride; healthy social narcissism; self-actualization; self-transcendence; customer citizenship behavior; SEM (structural equation modeling)

\section{Introduction}

As the food-service industry, one of the largest sales and private-sector employers [1], has been a significant source of a negative environmental impact [2], it should be seriously investigated in terms of sustainability. As the food-service industry accounts for about $30 \%$ of the global greenhouse gases [3], it is consistently ranked in the top three sources of global negative environmental impact, followed by the buildings and the transportation industry $[4,5]$.

Revell and Blackburn [6] found that only $29 \%$ of the restaurants and hotels in the UK were measured by environmental impact as compared to $70 \%$ of the firms in the chemical sector. The restaurant industry has been mainly investigated in terms of regulation impacts and not the environmental practices of the industry; restaurateurs do not recognize the negative environmental impacts caused by restaurants [6]. However, the green trend in the restaurant industry has accelerated eco-friendly menu trends, environmental practices, and green qualities that seek animal welfare and health $[7,8]$. This trend is driven by consumers' increasing environmental concerns and restaurateurs' economic benefit-seeking behavior, such as energy saving [3], and it continues in the future with the growth of green markets based on consumers' green preferences [9].

With the growth of consumers' environmental concerns and ethical consumption and the food-service industry's reactions to social pressures related to environmental responsibilities, the number of green restaurants is increasing [10]. A green restaurant can be defined as "a restaurant that offers a selection of green food menu items that use locally grown or organic certified food, as well 
as one that implements green practices, such as a recycling program, the efficient use of energy and water, and the reduction of solid waste" [11] (p. 804).

As compared to the growing number of studies $[12,13]$ on the hospitality industry's environmental initiatives and actives, research on the environmental initiatives of restaurants is limited, in particular, research on consumer behavior regarding green restaurant is scarce. Many studies (e.g., [14,15]) on green restaurants examine general consumers' intention to visit green restaurants. Theory of planned behavior (TPB) or the theory of reasoned action (TRA,) [16] have been mostly used to understand the factors influencing consumer intentions. The influence of other factors, such as consumers' perceived value [17] and green restaurant attributes [18], on intentions to visit green restaurants are also investigated.

Consumers need to spend time and energy to visit green restaurants including searching for the locations of green restaurants, as restaurants are a location-specific service, and obtaining information on their credibility. As the information on green restaurants are not readily available and accessible, consumers may have some difficulties in visiting green restaurants [19]. Golding and Peattie [20] suggested that the availability of green products should be investigated. Additionally, consumers may face a trade-off between traveling to visit distant green restaurants and visiting local ordinary restaurants, and this trade-off creates a dilemma for ethical consumers [21]. Accordingly, ethical consumers who have undergone difficult processes for ethical consumption may have pride in their ethical consumption. Pride mediates passion and moral behavior [22]. There is also evidence that pride motivates prosocial behavior [23]. Goal-achievement generates positive self-appraisal and self-esteem, which in turn, produces pride. However, previous studies have not sufficiently explored their pride [19]. As narcissists seek to impress and gain admiration from others, they tend to consider the symbolic value of products or services [24] rather than their utilitarian value. They tend to purchase green products for altruism and their green consumption seems to be motivated by social admiration and visibility [25]. Communal narcissists exaggerate helpfulness or care as communal features and communal knowledge in the agent-communal model [26]. Green restaurant consumers with healthy social narcissism may regard green restaurant consumption as a good vehicle to gain social visibility and admiration. More importantly, co-existence of altruistic and egoistic motivations of ethical consumers and complexity of motivations have been discussed in the literature on ethical consumers (e.g., $[27,28])$. However, there is a shortage of research on green restaurant consumers' egoistic or self-oriented motivations, such as self-actualization, while altruistic motivations including moral obligation or empathy have been well-researched [27]. Moreover, research in the relationships between ethical consumers' feelings, such as pride or guilt, and their motivations on ethical consumption has been insufficient.

Although green restaurants are growing with the growth in ethical consumers' demands, research on green restaurants largely remains as hypothetical, because most research on green restaurant consumers focuses on general consumers' intention to use green restaurants rather than actual green restaurant consumers. The social desirability that leads the ethical tendency of consumers $[29,30]$ has been a common problem for studies measuring general consumers' ethical intention.

To fill the research gap, the objective of this study is to investigate factors influencing ethical consumers' green restaurant loyalty and cooperation with respect to consumer citizenship behavior (CCB) as advanced voluntary behaviors that help and advocate service providers. CCB involves consumers' extra-role behaviors that include cooperation, participation, word-of-mouth (WOM) communication, and helping actions towards other customers, employees or firms [31]. This study explores self-actualization and self-transcendence motivations leading to ethical consumers' CCB. By investigating the influence of ethical consumers' self-actualization as a self-oriented motivation and self-transcendence as an altruistic motivation on CCB simultaneously, this study attempts to provide useful theoretical and practical insights for the research on ethical consumers and the literature on the green restaurant. The influence of pride on self-actualization and that of healthy social narcissism on 
self-transcendence are investigated, which makes theoretical contribution on the literature of ethical consumers' emotions and psychological traits.

\section{Theoretical Background and Hypotheses}

\subsection{Motivations for Ethical Consumption}

Motivations refer to "the drives, urges, wishes, or desires which initiate the sequence of events known as "behavior" [32] (p. 282). They occur when a "need is aroused that the consumer wishes to satisfy" [33] (p. 91). Co-existence of altruistic and egoistic motivations of ethical consumers and complexity of motivations have been discussed in the literature on ethical consumers (e.g., [27,28]). Arnocky, Stroink, and DeCiccoc [34] suggested three types of environmental concerns, egoistic, altruistic, and biospheric concerns based on self-construal concepts. Egoistic environmental concerns based on independent self-construal concepts are positively associated with self-enhancement [35], while altruistic ones based on interdependent self-construal concepts are positively associated with self-transcendence [34]. Biospheric environmental concerns based on meta-personal self-construal concepts emphasize the inherent value of environment and correlate with self-transcendence, but not with self-enhancement.

Personal values defined as "concepts or beliefs about desirable end states or behaviors that transcend specific situations, guide selection or evaluation of behavior and events, and are ordered by relative importance" [36] (p. 551). They are "socially approved as verbal representations of basic motivations" [37] (p. 137). Self-enhancement (power and achievement) and self-transcendence (universalism and benevolence) represent one of the two basic bipolar dimensions of umbrella value domains covering 10 types of values in Schwartz's [38] well-known value theory. Most studies (e.g., $[35,37,39])$ support the basic idea that as unethical consumer practices engage in focusing on personal interests even at the cost of others, self-enhancement tends to agree with unethical dispositions, while self-transcendence tends to be consistent with ethical dispositions because ethical consumers try to avoid ethical transgressions that can harm others.

Although self-enhancement can be congruent to egoistic environmental concerns [34], many studies (e.g., $[35,37,39]$ ) have found that self-enhancement is negatively associated with an environmental disposition or behavior. Thus, self-enhancement seems to be controversial in being considered as an ethical motivation. More importantly, self-enhancement may limit the contents of egoistic ethical motivations to functional consequences; for example, organic food or environment friendly products for health. However, ethical consumers have psychological or value-driven egoistic, self-oriented, or self-conscious ethical motivations [27].

This study is based on the model of value-motivated behavior highlighting that values are motivations of behavior [40]. The value-belief-norm (VBN) theory that explains the movement of environmentalism proposes that personal values become the primary aspect of the green behavior [41]. Self-actualization and self-transcendence as motivations for ethical consumption may lead consumers' green restaurant consumption. Moreover, we link pride to self-actualization driving $\mathrm{CCB}$, and healthy social narcissism as hubristic pride to self-transcendence driving $\mathrm{CCB}$, similar to the well-known empathy-altruism hypothesis $[42,43]$ postulating that the greater the empathy, the greater the altruistic motivation that drives the altruistic behavior.

\subsection{Hypothesis Development}

Self-actualization, which is a basic motivation and an integrated type of self-development [44] and self-enhancement, may be an appropriate self-oriented concept to understand ethical consumers' motivations. Encompassing "a basic drive toward growth, completeness, and fulfillment" [45] (p. 598), self-actualization can be regarded as a basic motivation for seeking self-fulfillment [46]. Knapp [47] suggested that self-actualization emphasizes the development of an effective and self-fulfilled person [47]. Maslow [48] described self-actualization as "the [person's] desire for self-fulfillment, 
namely, to the tendency for him to become actualized in what he is potentially" [48] (p. 382). Self-fulfillment, as an internally oriented value in Homer and Kahle's [49] value system, is positively linked to environment-friendly consumption [50]. Hwang and Kim [27] found that self-actualization was a vital motivation for ethical consumers' fair-trade coffee repurchase.

Levenson et al. [51] explained self-transcendence as "being able to detach from the external definitions of the self and dissolving rigid boundaries between self and other allows for self-transcendence" [51] (p. 129). Self-transcendence, which has been proved as an altruistic value and motivation, was placed in Maslow's new hierarchy of motivation and it drives individuals to pursue communal benefits beyond purely personal interests [52]. Self-transcendence reduces attachment to individuals' own perspectives, and construal self and increases the extension of care and concern toward others [53]. Koltko-Rivera [52] argued that self-transcendence goes beyond the pure self and enables individuals to involve themselves in the service of others, thus surpassing self-actualization in Maslow's hierarchy.

Beaumont [54] used self-actualization as a self-related facet and self-transcendence as a social-cognitive process as a framework of personal wisdom in his study, which argued that "self-actualization involves advanced self-development or actuation of growth, whereas self-transcendence involves an ability to expand or transcend the boundaries of one's ego identity" [54] (p. 100). Although the previous literature on ethical motivations mainly focuses on altruistic facets (as ethical consumer motivations include both self-oriented or self-conscious and altruistic or social facets), this study proposes a framework of ethical consumers' motivation based on self-actualization and self-transcendence to yield a novel insight of ethical consumers' value-driven ethical consumption processes.

As a self-conscious emotion, pride involves self-evaluative processes which produce behavioral standards [55]. Pride, a pleasant feeling, and positive self-approval are elicited when individuals do something right or good [56]. Pride as a moral emotion plays as a moral gauge promoting morally and socially acceptable behavior [57]. As Mascolo and Fischer [58] emphasized that pride is produced by appraisals associated with responsibility for prosocial outcome and socially valued individuals, pride promotes prosocial behavior as well self-worth. Pride as an ego-focused emotion involves internal state and is closely linked to expression, awareness, and experience [25]. Carver, Sinclair, and Johnson [59] argued that pride can be categorized as authentic pride (i.e., feelings of self-worth and self-esteem evoked by self-accomplishment and long-term goal achievement) and hubristic pride (i.e., narcissistic self-aggrandizement based on short-term goal-attainment). Authentic pride is positively linked to self-control [60] and achievement [61].

Authentic pride aids in making moral decisions; for example, a decision to allocate resources among group members [62]. Pride mediates passion and moral behavior [22]. There is also evidence that pride motivates prosocial behavior [23]. Goal-achievement generates positive self-appraisal and self-esteem, which in turn, produces authentic pride. Green restaurant consumption incorporates long-term and short-term goal-driven behaviors [63] that often require complicated decision-making with time and energy consumption to search for information and a choice in a trade-off between different ethical behaviors [21]. In these green restaurant consumption processes, ethical consumers may feel pride based on the achievement of their value and life goal through green restaurant consumption, which often require efforts and problem-solving processes. The authentic pride is based on accomplishments and produces genuine self-worth [64]. Maslow [65] argued that one's pride in his/her accomplishments became the expression of achieving progress toward self-actualization. This pride, which is based on self-achievement, self-growth, and positive self-esteem, may lead to the self-actualization of ethical consumers. Thus, this study establishes the following hypothesis:

Hypothesis 1. Pride in green restaurant service consumption is positively associated with green restaurant consumers' self-actualization. 
In this study, the antecedent of self-actualization includes pride. Further, it uses healthy social narcissism as the antecedent of self-transcendence. Healthy social narcissism as a hubristic pride, which is closely linked to pride, and the authentic/hubristic $(\mathrm{A} / \mathrm{H})$ model of pride [64] proposes the pride and narcissism relationships. As discussed, hubristic pride, which is different from authentic pride, is regarded as narcissistic self-aggrandizement and is viewed as a negative psychological trait causing aggressive and antisocial behavior $[59,66]$. However, narcissism, closely linked to pride and high self-esteem, can be viewed normally and positively rather than as a pathological and dysfunctional perspective [25]. The growing number of narcissists [67] and non-clinical normal research subjects who indicate psychological traits related to narcissism may make us consider normal or healthy narcissism. According to Naderi and Strutton [25], two levels of narcissism exist: negative narcissism, which is "clinical, unhealthy, or pathological narcissism," and positive narcissism, which is "subclinical, healthy, or normal narcissism" [25] (p. 376). Self-esteem, which has been proven to have consistent and positive link to narcissism (e.g., $[68,69])$, is a vital component of healthy narcissism, and is closely associated with subjective wellbeing [70] and psychological health. Healthy narcissism embraces a positive aspect of self that focuses on self-investment derived from self-realization [71] and personal growth [72], thus leading to the actualization of one's abilities or potentialities. Moreover, healthy narcissism, assisted by self-esteem [73], leads to subjective wellbeing [74]. Hwang and Kim [27] also found the positive association between healthy social narcissism and self-actualization in the context of fair-trade coffee repurchases.

As narcissists seek to impress and gain admiration from others, they tend to consider the symbolic value of products or services [24] rather than their utilitarian value. They tend to purchase green products for altruism and their green consumption seems to be motivated by social admiration and visibility [25]. The narcissistic personality inventory (NPI) comprises four factors including self and social aspects. The leadership/authority dimension correlates with social responsibility, which influences the criticism of the view that narcissism is exclusively a pathological trait and indicates the complexity of narcissism [75]. The leadership/authority factor represents the ability to influence others and the confidence to be a good leader [76]. A narcissist might consume ethical products or services to gain leadership to demonstrate their practices of social responsibility. The leadership ability in the NPI is found to be linked to positive interpersonal outcomes, which results in the manifestation of pro-social behavior [77].

Additionally, narcissism is classified into agentic and communal narcissism in an agency-communion model $[26,78]$. Communal narcissists exaggerate helpfulness or care as communal features and communal knowledge in the agent-communal model, which holds that "narcissism may be understood as an agency-communion trait: an agentic trait that is expressed through communal means" [74] (p. 855). Although communal narcissism inventory $[26,78]$ has been used to measure positive social narcissism, this study emphasizes the existence of healthy or positive social narcissism. Leadership/authority and some other elements of the NPI also exhibit healthy social narcissism. Healthy social narcissists may engage in ethical consumption for social benefit and responsibilities to prove their ethical leadership and enhance their grandiose self-image. Green restaurant consumers with healthy social narcissism may regard green restaurant consumption as a good vehicle to gain social visibility and admiration, because green restaurant consumption is visible and social. Healthy social narcissism or communal narcissism develops self-other relationships and serves interpersonal or social benefits, which can lead to self-transcendence. Thus, the following hypothesis is proposed:

Hypothesis 2. Healthy social narcissism is positively associated with self-transcendence.

Self-transcendence as an altruistic value and motivation, was placed in Maslow's new hierarchy of motivation and it drives individuals to pursue benevolent benefits beyond purely personal interests [52]. Maslow [79] included a new zenith, self-transcendence, in his pyramid, and placed it on top of the pyramid. Self-transcendence facilitates self-actualization, and leads individuals to connect to outside 
of the self. Reischer et al. [80] contend that "this simultaneity of self-actualization and deep connection to others illustrates the sympathetic nature of self-transcendence". Koltko-Rivera [52] argued that self-transcendence enables individuals to involve themselves in the service of others, thus surpassing self-actualization in Maslow's hierarchy.

Hypothesis 3. Self-actualization is positively associated with self-transcendence.

Although traditional value research focuses on a utilitarian functional value $[81,82]$ that determines purchase and repurchase intentions (e.g., [83-85]), a perspective of multidimensional value is suggested as a more appropriate view in the context of services $[85,86]$. Consumers may seek socio-psychological value due to the relatively close interaction between service providers and consumers and the heterogeneity of service experiences [87].

The model of value-motivated behavior highlights that values, typically regarded as the determinants of attitudes and behavior, are motivations of behavior [40]. The value-belief-norm (VBN) theory that explains the movement of environmentalism with the emphasis of attitudinal and behavioral changes proposes that personal values become the primary aspect of the green behavior [41]. Self-actualization and self-transcendence as motivations for ethical consumption may lead consumers' green restaurant consumption. When consumers' personal values are achieved through service values, consumers are satisfied with the service [88]. Zhang and Bloemer [89] found that value congruence, measured by consumers' perceptions of value congruence between service brand values and their personal values (measured by the Schwartz value), affects their loyalty and positive WOM (word-of mouth).

Some consumers behave more advanced activities than loyalty and WOM to support their favorite brands. Customer voluntary performance (CVP) can be defined as "helpful, discretionary behaviors of customers that support the ability of the firm to deliver service quality" [90] (p. 384). Recently, customer citizenship behavior (CCB) has received attention [91-93]. Groth defined CCB as "voluntary and discretionary behavior of individual customers that is not directly or explicitly expected or rewarded but that in the aggregate, leads to higher quality service and promotes the effective functioning of service organizations" [92] (p. 13). CCB is especially relevant to service firms [94]. According to Fowler [31], CCB has seven dimensions, including affiliation, cooperation, WOM communication, participation, customer voice, flexibility, and policing of other customers. Additionally, Yi and Gong [95] proposed four dimensions of CCB, including feedback from customers to the employees, tolerance related to patience in case of service failure, advocacy and helping other customers. $\mathrm{CCB}$ results in benefits to the customers themselves and other customers as well as service providers [96]. Bettencourt [90] presented three broad dimensions of CCB, including loyalty ("customer behaviors indicating allegiance to and promotion of the organization's interests beyond individual interests", p. 385), cooperation ("discretionary customer behaviors indicating respect for the provision of quality service delivery". p. 386) and participation ("customer behaviors indicating active and responsible involvement in the governance and development of the organization", p. 386). The three sets of CCB dimensions overlap with each other; we used Bettencourt's [90] three dimensions that more broadly cover customers' voluntary behaviors. CCB creates value to customers themselves by providing the sense of belonging, social interaction with other customers, being useful by helping employees and giving feedback to staff [97]. As ethical consumers can achieve ethical values when they visit green restaurants where ethical practices are carried out, which may lead ethical CCB toward green restaurants [19]. The green restaurant becomes a value satisfier for ethical consumers. Thus, a green restaurant service can let ethical consumers achieve their ethical values, which drive them to perform CCB to maintain their value fulfilment.

Hypothesis 4. Ethical consumers' self-actualization is positively associated with their CCB.

Hypothesis 5. Ethical consumers' self-transcendence is positively associated with their CCB. 
The research model includes pride (emotion) and healthy social narcissism (hubristic pride) as influencing factors on self-actualization and self-transcendence as values that lead CCB (Figure 1). It is based on the value.

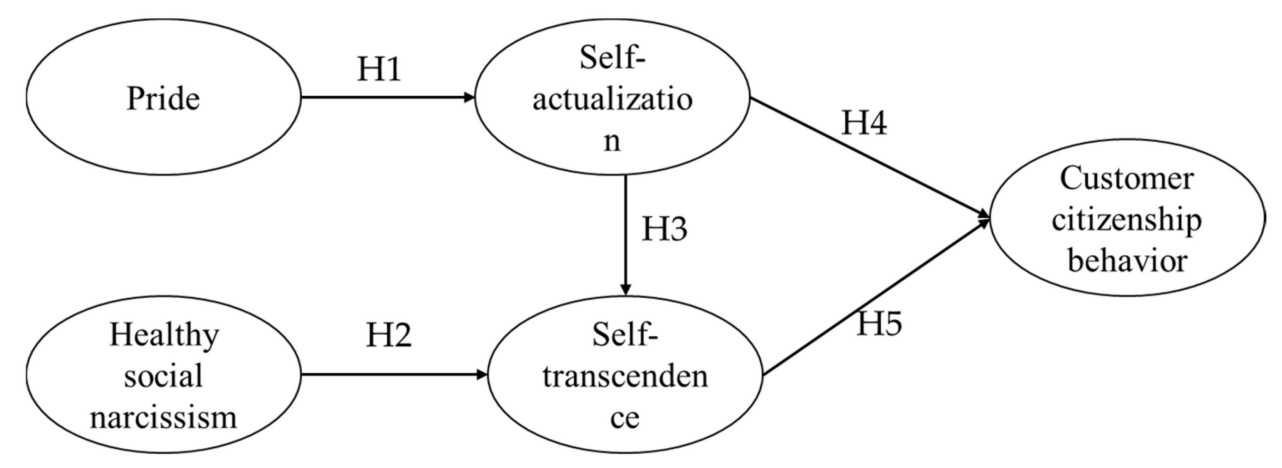

Figure 1. The research model and hypotheses.

\section{Method}

\subsection{Research Design}

To test our research model, this study employed latent variable structural equation modeling [98] using maximum likelihood estimation in AMOS 21. AMOS is effective for predicting or identifying key target constructs of the research model, while structural equation modeling (SEM) is more suitable for testing or confirming theories [99]. SEM simultaneously estimates the structure within a series of dependence relationships between latent variables with multiple indicators while correcting for measurement errors [100]. This study applied research constructs from the literature to our research model. Very few studies have empirically tested the relationships among ethical consumers' self-actualization or self-transcendence and CCB. This paper identifies key target constructs in the research model and the strong path relationships among them. Consequently, the AMOS method is an appropriate analysis tool for the main objective of this study. As Hair et al. recommend [95], we calculated four fit indices to determine how the model fitted the data: $\chi^{2}$, comparative fit index (CFI), Turker-Lewis Index (TLI), root mean square error of approximation (RMSEA). For CFI and TLI, values greater than 0.9 represent a good model fit, and for RMSEA a value less than 0.07 indicates a good model fit [101].

\subsection{Measures}

The survey was conducted with a Korean version instrument translated from the English version. In order to ensure the reliability and validity of the scales, we first translated the questionnaire into Korean language. A focus group interview (FGI) with 6 researchers and 6 postgraduates was run to check "translate-back translate" procedure for avoiding any possible mistranslation. On the other hand, another FGI with 10 participants including green restaurant consumers, experts on ethical consumers, and postgraduate students was performed to review the initial Korean survey and give constructive advice on modification. Second, we administered post-FGI with same participants of 6 researchers and 6 postgraduates to confirm the appropriateness and comprehensibility of the questionnaire. These tasks were performed in June 2016.

The scale items for all variables were measured on a seven-point Likert scale ranging from "strongly disagree" (1) to "strongly agree" (7). The items for pride were derived from Kim and Johnson's [102] three-item scale. The items for healthy social narcissism were based on Ames, Rose, and Anderson's [103] shorter version of the narcissism personality inventory (NPI), which was reduced by Raskin and Terry's NPI [104]. In order to denote healthy social narcissism, we administered FGI interviews with 12 researchers and postgraduate students and selected two items for leadership, one item for authority, and one item for entitlement [105]. 
The self-actualization items were taken from Phang et al.'s [106] five-item scale. Moreover, the self-transcendence items were taken from Nordlund and Garvill's [107] six-item scale [108,109]. The CCB items were taken from Bettencourt's [91] research's 17-item scale. However, two items of CCB were eliminated from the FGIs because they lacked item appropriateness. For example, "Even if a price is incorrect to my advantage, I still advise someone at this store" was an improper item to use when consumers already accepted the proper premium of green restaurants. If the prices in the restaurant menu are too high, consumers will not be satisfied with its service, thus inhibiting consumers' CCB in the FGIs.

\subsection{Data Collection}

The second author distributed the survey questionnaire to 551 regular green restaurant customers in Seoul, including Dr. Robbin, Seven Springs, Yaksikdongwon, and environmental-friendly agricultural product restaurants, between 1 March and 30 June 2017. As the study focused only on regular customers of green restaurants, we used judgmental sampling as a form of nonprobability sampling for sample selection. As there are only a few green restaurants in Korea, the second author visited those green restaurants and administered a survey through a personal survey method. A total of 551 questionnaires were collected, 343 (62\%) of which were used in the analysis. We used a screening question, "Are you a customer of this green restaurant because you are an ethical consumer?" to select only ethical consumers who are green restaurant customers, as some consumers visit green restaurants without an ethical purpose. Based on the screening question, 164 questionnaires were discarded on the basis of consumers visit to green restaurants without any ethical purpose. Incomplete and unreliable responses were carefully checked, and 44 questionnaires were eliminated accordingly. Table 1 presents the respondents' demographic characteristics.

Table 1. Demographic characteristics of respondents.

\begin{tabular}{|c|c|c|c|c|c|}
\hline Description & Frequency & Composition (\%) & Description & Frequency & Composition (\%) \\
\hline \multicolumn{4}{|c|}{ Frequency of visiting green restaurants (per month) } & \multicolumn{2}{|c|}{ Education } \\
\hline Once & 241 & 70.3 & High school or less & 8 & 2.3 \\
\hline $2-3$ times & 78 & 22.7 & College student & 48 & 14.0 \\
\hline $4-5$ times & 13 & 3.8 & Graduated college & 218 & 63.6 \\
\hline $6-7$ times & 6 & 1.7 & College drop-out & 9 & 2.6 \\
\hline Over 8 times & 5 & 1.5 & $\begin{array}{l}\text { Graduated from } \\
\text { graduate school }\end{array}$ & 60 & 17.5 \\
\hline \multicolumn{3}{|c|}{ Gender } & \multicolumn{3}{|c|}{ Income } \\
\hline \multirow{3}{*}{ Male } & \multirow{3}{*}{73} & \multirow{3}{*}{21.3} & If income < USD 1000 & 76 & 22.2 \\
\hline & & & USD 1000-less than 2000 & 71 & 20.7 \\
\hline & & & USD 2000-less than 3000 & 77 & 22.4 \\
\hline \multirow[t]{2}{*}{ Female } & \multirow[t]{2}{*}{270} & \multirow[t]{2}{*}{78.7} & USD 3000-less than 4000 & 53 & 15.5 \\
\hline & & & USD 4000 or more & 66 & 19.2 \\
\hline \multicolumn{3}{|c|}{ Age } & \multicolumn{3}{|c|}{ Occupation } \\
\hline Under 20 & 2 & 0.6 & College student & 78 & 22.7 \\
\hline $20-29$ & 133 & 38.8 & Office worker & 102 & 29.7 \\
\hline $30-39$ & 121 & 35.3 & Specialized job & 70 & 20.4 \\
\hline $40-49$ & 49 & 14.3 & Self-employed & 17 & 5.0 \\
\hline $50-59$ & 35 & 10.2 & Housewife & 65 & 19.0 \\
\hline 60 or more & 3 & 0.9 & Others & 11 & 3.2 \\
\hline \multicolumn{6}{|c|}{ Total $343(100 \%)$} \\
\hline
\end{tabular}

\subsection{Data Analysis and Results}

\subsubsection{Preliminary Analyses}

We validated measurements using confirmatory factor analysis (CFA) entering 33 items for five multi-item constructs, pride, healthy social narcissism, self-actualization, self-transcendence, 
customer citizenship behavior, into one analysis. This process was done based on two-step analysis. This result showed a poor model fit $(\mathrm{CFI}=0.838$, $\mathrm{TLI}=0.822)$. Then we deleted items loading below 0.6 on their constructs [110]. Deleted items are: one item from healthy social narcissism, "I think that I would be a good leader", two items from self-transcendence, "Equality is a guiding principle in my life" and "Social justice is a guiding principle in my life", and four out of seventeen items for CCB, e.g., "When I experience a problem at the green restaurant, I let someone know so they can improve service" and "If I have a useful idea on how to improve service, I give it to someone at the green restaurant". After these modifications deleting seven items, we repeated CFA with 26 parameters to verify the convergent and discriminant validity of the measures. The convergent validity of the constructs was calculated by a test of the average variance extracted (AVE). The results were all over 0.5 [111], that is, between 0.513 and 0.646 , which indicate their acceptable convergent validity. The results of the construct reliability tests for all variables are over 0.7 , between 0.756 and 0.920, which indicates their acceptable construct reliability (see Table 2). The results showed an acceptable model fit $\left(\chi^{2}=720.975, \mathrm{df}=282, \mathrm{CFI}=0.929\right.$, TLI $=0.919$, RMSEA $\left.=0.067\right)$, indicating that the measurement scales showed validity.

Table 2. Validity and reliability of the reflective constructs.

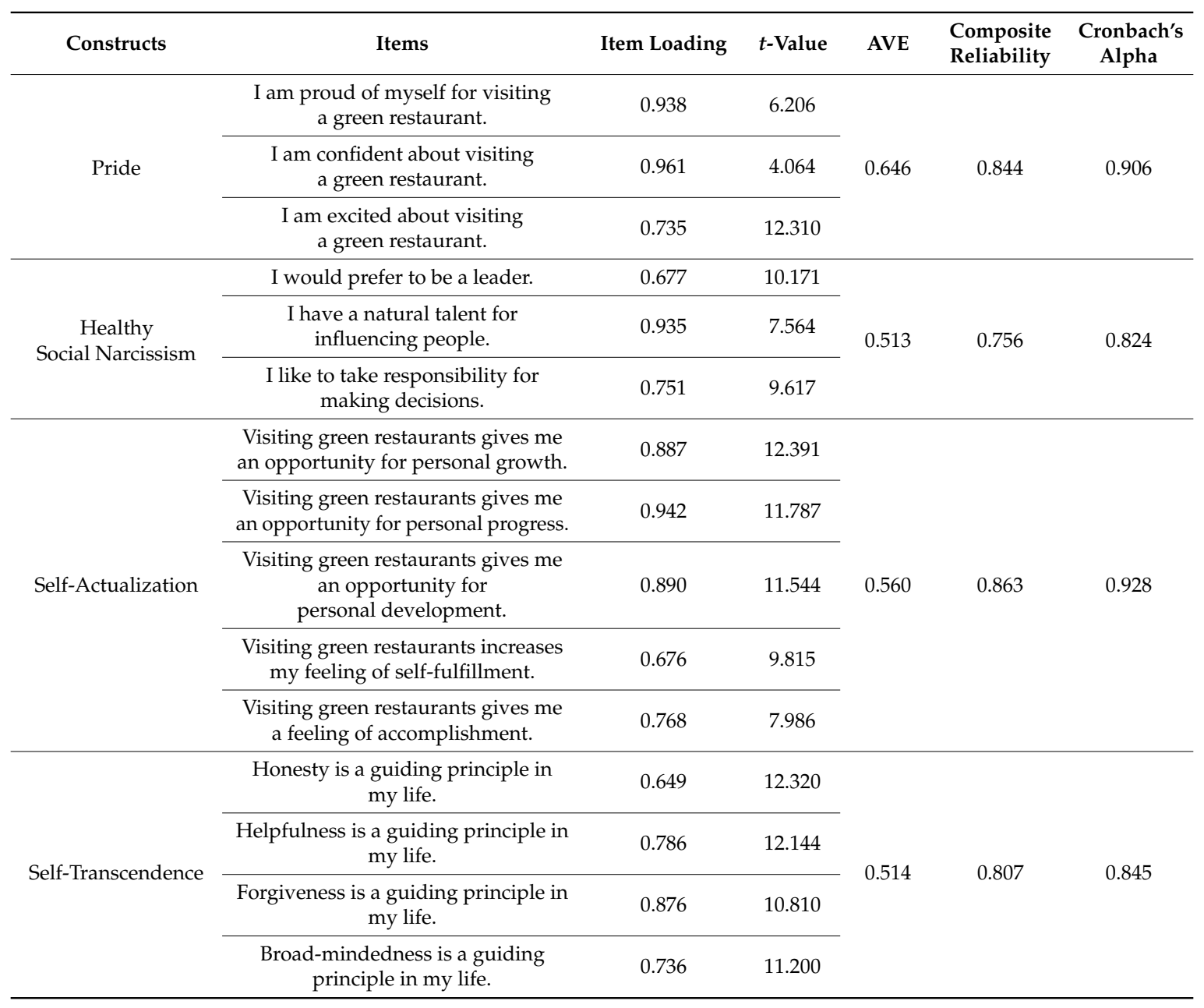


Table 2. Cont.

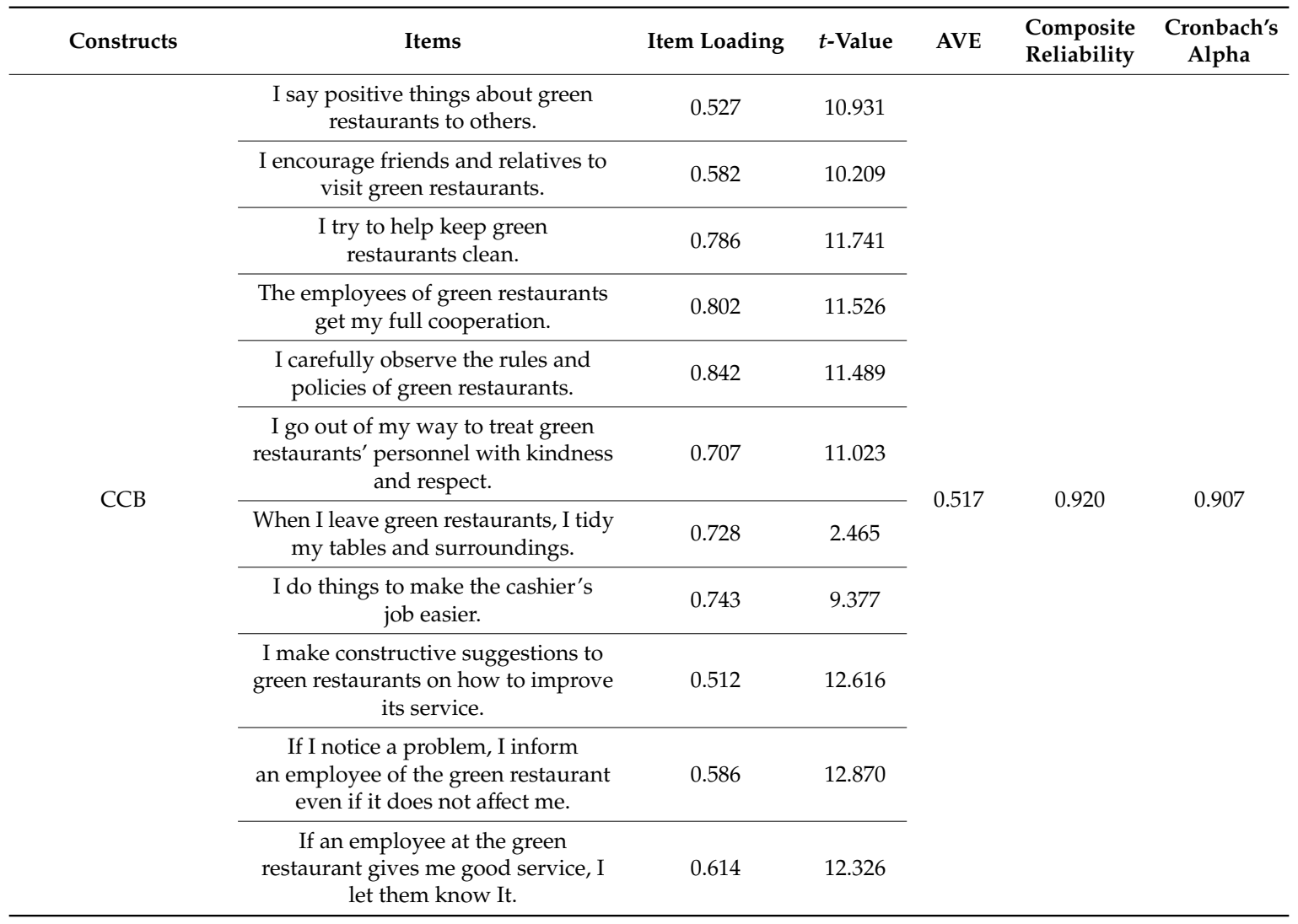

Table 2 presented the results of preliminary analyses including CFAs and reliability tests. Throughout these jobs, we assessed the reliability and validity of the measurement scales. The reliability of constructs was estimated using Cronbach's alpha coefficients. The Cronbach's alpha for all the variables range from 0.824 to 0.928 , which indicates that they are within the acceptable range [111].

Correlations and descriptive statistics for the research variables are presented in Table 3. The discriminant validity for all constructs is established when a diagonal value is higher than the values in other rows and columns. Meanwhile, the square roots of the AVE values in Table 3 exceed the value of correlations, which verifies discriminant validity [112].

Table 3. Mean, standard deviation, and correlations for the variables.

\begin{tabular}{cccccccc}
\hline & $\mathbf{M}$ & SD & $\mathbf{1 .}$ & $\mathbf{2 .}$ & $\mathbf{3 .}$ & $\mathbf{4 .}$ & $\mathbf{5 .}$ \\
\hline 1. P & 4.292 & 1.292 & $\mathbf{0 . 8 0 4}$ & & & & \\
2. HSN & 4.913 & 1.120 & $0.212^{* *}$ & $\mathbf{0 . 7 1 6}$ & & & \\
3. SA & 4.538 & 1.218 & $0.621^{* *}$ & $0.159^{* *}$ & $\mathbf{0 . 7 4 9}$ & & \\
4. ST & 5.279 & 0.095 & $0.223^{* *}$ & $0.159^{* *}$ & $0.360^{* *}$ & $\mathbf{0 . 7 1 7}$ & \\
5. CCB & 5.045 & 0.910 & $0.507^{* *}$ & $0.177^{* *}$ & $0.459^{* *}$ & $0.279^{* *}$ & $\mathbf{0 . 7 1 9}$ \\
\hline
\end{tabular}

** $p<0.01$. The diagonal values (in bold) is the square root of average variance extracted (AVE). P: Pride; HSN: Healthy social narcissism; SA: Self-actualization; ST: Self-transcendence; CCB: Customer citizenship behavior.

Given that our data were collected from a single source, the procedures recommended by Podsakoff et al. [113] were followed to remedy the influence of common method bias. We conducted the Harman's single-factor test, the most commonly used technique for addressing common method variance [113]. Then we compared the Harman's single-factor CFA solution to the original five-factor measurement model and found that the single-factor model indicated a worse fit $\left(\chi^{2}=2930.642\right.$, $\mathrm{df}=292, \mathrm{CFI}=0.575, \mathrm{TLI}=0.527$, RMSEA $=0.163$ ). After we added an orthogonal latent common method factor to the theoretical model in order to assess the potential increase in model fit, we found: 
$\Delta \chi^{2}=2930.642, \Delta \mathrm{df}=10, p<0.001$. In addition, the first principal component accounted for only $34.15 \%$ of the total variance. In this research with the five factor measurement model, the results report that our research model is valid and is not seriously compromised by common method bias.

\subsubsection{Hypothesis Tests}

The next step is to evaluate the results of the structural model, its effects, and the significance of the results. In the measurement model, where the loadings represent the reflective indicator and the weights represent the formative indicators, the AMOS method produces loadings and weights [111]. The loadings, $t$-values, and significance of the path coefficients were calculated to analyze the structural model. The bootstrapping algorithm with 1000 times was calculated to assess the path (see Table 4). We conducted structural equation modeling to test the hypotheses. The hypothesized model provided a good fit for the data $\left(\chi^{2}=736.070, \mathrm{df}=286, \mathrm{CFI}=0.928, \mathrm{TLI}=0.918, \mathrm{RMSEA}=0.068\right)$ and the majority of our hypotheses were supported by the data.

Table 4. Testing results of the structural model.

\begin{tabular}{|c|c|c|c|c|}
\hline & Structural Model Path & $\beta$ & $t$ Statistics & Result \\
\hline $\mathrm{H} 1$ & Pride $\rightarrow$ Self-Actualization & $0.624 * * *$ & 12.426 & Accepted \\
\hline $\mathrm{H} 2$ & Healthy Social Narcissism $\rightarrow$ Self-Transcendence & $0.129 * *$ & 2.206 & Accepted \\
\hline $\mathrm{H} 3$ & Self-Actualization $\rightarrow$ Self-Transcendence & $0.362 * * *$ & 5.874 & Accepted \\
\hline $\mathrm{H} 4$ & Self-Actualization $\rightarrow$ Customer Citizenship Behavior & $0.398^{* * *}$ & 5.761 & Accepted \\
\hline H5 & Self-Transcendence $\rightarrow$ Customer Citizenship Behavior & $0.136^{* *}$ & 2.200 & Accepted \\
\hline
\end{tabular}

Hypothesis 1 (pride is positively associated with self-actualization) is supported ( $\beta=0.624$, $p<0.01$ ). Hypothesis 2 (healthy social narcissism is positively associated with self-transcendence) is supported $(\beta=0.129, p<0.05)$. Hypothesis 3 (self-actualization is positively associated with self-transcendence) is supported $(\beta=0.362, p<0.01$ ). Hypothesis 4 (self-actualization is positively associated with CCB) is supported $(\beta=0.398, p<0.01)$. Hypothesis 5 (self-transcendence is positively associated with $\mathrm{CCB})$ is supported $(\beta=0.136, p<0.05)$. Figure 2 depicts the results of the research model analysis.

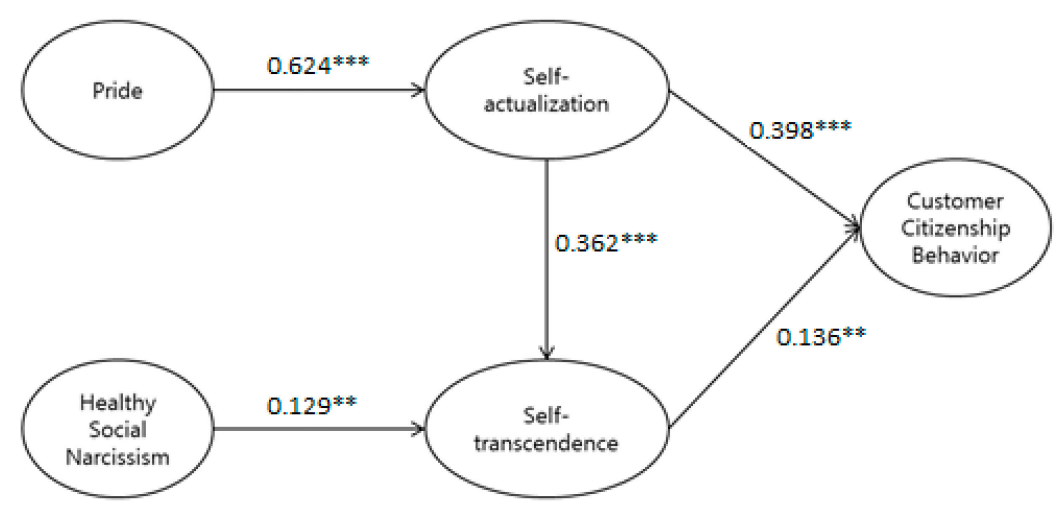

Figure 2. The test results of research model. ${ }^{* *} p<0.01 ;{ }^{* * *} p<0.001$.

In addition, an assumption of the model proposed by this research contains several indirect paths. In order to determine the significance of indirect effect of the independent variable on the dependent variable through mediator variables, the bootstrap method was used in this study. As our data are not normally distributed as found through normality tests and mediation tests, such as the Sobel test, an assumption of normal distribution is not appropriate [114]. For a skewed distribution of data, bootstrapped sampling distribution becomes an alternative approach [114]. The bootstrapping approach displays a confidence interval with empirically bootstrapped sampling 
distribution. Thus, we used AMOS 21 using 1000 bootstrap samples to examine indirect effect. Specifically, bootstrapped confidence interval (CI) estimates for the indirect elects of pride and healthy social narcissism on customer citizenship behavior through self-actualization and self-transcendence were calculated. The bootstrapping process essentially consists of estimating the indirect effect of independent variables using a large number of random resamples. Table 5 shows bootstrap results for mediator paths of our research model.

Table 5. Bootstrap estimates of cross-sectional indirect effects.

\begin{tabular}{cccccc}
\hline \multirow{2}{*}{ Indirect Effect } & Point Estimate & \multirow{2}{*}{ SE } & \multicolumn{2}{c}{ 95\% Confidence Level } & \multirow{2}{*}{ Result } \\
\cline { 5 - 6 } & & & Lower & Upper & \\
\hline $\mathrm{P} \rightarrow \mathrm{SA} \rightarrow \mathrm{ST}$ & $0.244^{* *}$ & 0.051 & 0.146 & 0.346 & Accepted \\
$\mathrm{P} \rightarrow \mathrm{SA} \rightarrow \mathrm{CCB}$ & $0.168^{* *}$ & 0.046 & 0.083 & 0.264 & Accepted \\
$\mathrm{SA} \rightarrow \mathrm{ST} \rightarrow \mathrm{CCB}$ & $0.055^{*}$ & 0.028 & 0.009 & 0.115 & Accepted \\
$\mathrm{HSN} \rightarrow \mathrm{ST} \rightarrow \mathrm{CCB}$ & 0.019 & 0.014 & -0.003 & 0.051 & Rejected \\
\hline
\end{tabular}

1 Point estimates are standardized estimates. Bootstrap sample 1000. ${ }^{*} p<0.05 ;{ }^{* *} p<0.01$. P: Pride; HSN: Healthy social narcissism; SA: Self-actualization; ST: Self-transcendence; CCB: Customer citizenship behavior.

In our research model, self-actualization potentially mediated between pride, self-transcendence and CCB. In addition, self-transcendence potentially mediated between self-actualization and CCB and between healthy social narcissism and CCB. To test mediation, the direct paths between the predictors and outcomes were assessed. In this analysis, the model fits are $\chi^{2}=721.064, \mathrm{df}=283, \mathrm{CFI}=0.930$, $\mathrm{TLI}=0.919$, RMSEA $=0.067$. Pride $(\beta=0.258, p<0.001)$ and self-actualization $(\beta=0.227, p<0.01)$ were related to CCB. However, the direct effect of pride on self-transcendence and the direct effect of healthy social narcissism on CCB were not significant. Then, the indirect paths were assessed to calculate SEs and 95\% bias-corrected CIs. Mediation occurs when the $95 \%$ CIs of the indirect effect do not include zero [114]. As Table 5 shows, our results demonstrate as followed: The indirect effects of pride mediated by self-actualization on two variables, self-transcendence (CIs 0.146 to 0.346 ) and CCB (CIs 0.083 to 0.264 ) are statistically significant. The indirect effect of self-actualization mediated by self-transcendence on CCB (CIs 0.009 to 0.115 ) is statistically significant while healthy social narcissism's indirect effect on $\mathrm{CCB}$ is not.

\subsubsection{Robustness Tests}

We used SEM for our main testing of hypotheses for following reasons. First, SEM depends on maximum likelihood estimation. Second, the recommended minimum sample size in SEM is 10 to 20 times the number of parameters estimated [115]. Our research model contains 26 parameters while the sample size is 343 . Thus, it makes this ratio about 13.19. Among our research variables, customer citizenship behavior meets the required normality (Shapiro-Wilk: $0.058>0.05$ ) [116]. Thus, we employed an additional analysis to confirm our research results [117].

We tested the robustness of our results by conducting regression analyses for the customer citizenship behavior dependent variable. The regression analysis was repeated; pride $\left(\beta=0.614^{* * *}\right)$ and healthy social narcissism on self-actualization (Model 1), pride $\left(\beta=0.200^{* * *}\right)$ and healthy social $\operatorname{narcissism}\left(\beta=0.125^{* * *}\right)$ on self-transcendence (Model 2), pride, healthy social narcissism $\left(\beta=0.113^{*}\right)$, and self-actualization $\left(\beta=0.355^{* * *}\right.$ ) on self-transcendence (Model 3 ), and finally self-actualization $\left(\beta=0.409^{* *}\right)$ and self-transcendence $\left(\beta=0.134^{* *}\right)$ on customer citizenship behavior (Model 4). These analyses are shown in Table 6.

These results of the four models are qualitatively identical to our main analyses with SEM (structural equation modeling), confirming the robustness of our main analyses. All hypotheses supported in the main analyses were confirmed with regression analyses. We also tested our conceptual model adding two mediating variables in separate model, pride, healthy social narcissism, self-actualization, and self-transcendence on customer citizenship behavior (Model 5). It was necessary to test the combined analysis controlling pride and healthy social narcissism on customer citizenship behavior. 
We also found that self-actualization $\left(\beta=0.181^{* *}\right)$ and self-transcendence $\left(\beta=0.127^{* *}\right)$ are positively related to customer citizenship behavior, and results indicate significant main effects exist. These five analyses generated identical results for our hypothesis tests, supporting that our findings are robust.

Table 6. Regression analysis for CCB: model summary $(n=343)$.

\begin{tabular}{|c|c|c|c|c|c|c|c|c|c|c|}
\hline \multirow{3}{*}{ Variable } & \multirow{2}{*}{\multicolumn{2}{|c|}{$\begin{array}{c}\text { Model 1 } \\
\text { SA }\end{array}$}} & \multirow{2}{*}{\multicolumn{2}{|c|}{$\begin{array}{c}\text { Model } 2 \\
\text { ST } \\
\end{array}$}} & \multirow{2}{*}{\multicolumn{2}{|c|}{$\begin{array}{c}\text { Model } 3 \\
\text { ST }\end{array}$}} & \multirow{2}{*}{\multicolumn{2}{|c|}{$\begin{array}{c}\text { Model } 4 \\
\text { CCB } \\
\end{array}$}} & \multirow{2}{*}{\multicolumn{2}{|c|}{$\begin{array}{c}\text { Model } 5 \\
\text { CCB }\end{array}$}} \\
\hline & & & & & & & & & & \\
\hline & $\beta$ & $t$ & $\beta$ & $t$ & $\beta$ & $t$ & $\beta$ & $t$ & $\beta$ & $t$ \\
\hline $\mathrm{P}$ & $0.614^{* * *}$ & 14.321 & $0.200 * * *$ & 3.773 & -0.019 & -0.291 & & & $0.358^{* * * *}$ & 6.227 \\
\hline HSN & 0.033 & 0.761 & 0.125 ** & 2.354 & $0.113 *$ & 2.225 & & & 0.057 & 1.133 \\
\hline SA & & & & & $0.355^{* * *}$ & 5.602 & $0.409^{* * *}$ & 8.091 & $0.181 * *$ & 3.048 \\
\hline ST & & & & & & & $0.134^{* *}$ & 2.646 & $0.127^{* *}$ & 2.638 \\
\hline $\begin{array}{c}\text { Variance } \\
\text { Analysis Model }\end{array}$ & \multicolumn{2}{|c|}{$\mathrm{F}=109.63^{* * *}$} & \multicolumn{2}{|c|}{$\mathrm{F}=12.212^{* * *}$} & \multicolumn{2}{|c|}{$\mathrm{F}=19.314^{* * *}$} & \multicolumn{2}{|c|}{$\mathrm{F}=50.598^{* * *}$} & \multicolumn{2}{|c|}{$\mathrm{F}=38.871^{* * *}$} \\
\hline$R^{2}$ & \multicolumn{2}{|c|}{0.387} & \multicolumn{2}{|c|}{0.066} & \multicolumn{2}{|c|}{0.143} & \multicolumn{2}{|c|}{0.225} & \multicolumn{2}{|c|}{0.311} \\
\hline
\end{tabular}

\section{Discussions and Conclusions}

This study's central focus was to explore egoistic and altruistic motivations of green restaurant consumption and their influence on CCB simultaneously in a single model. Our hypotheses established that pride affects self-actualization and healthy social narcissism affects self-transcendence. Hwang and Kim [27] found the relationships between healthy narcissism and self-actualization, however the current study explored the relationships between healthy social narcissism and self-transcendence, which has not been previously investigated. In this study, we demonstrated the appropriateness of our research model and the hypotheses. However, interestingly, self-actualization affected by pride indicated a stronger impact on $\mathrm{CCB}$ than the other path, and the path from pride to self-actualization to $\mathrm{CCB}$ indicated stronger relationships. Self-conscious motivations for ethical consumption have not been sufficiently investigated in the previous literature. Moreover, the literature on ethical consumers does not address how ethical consumption experiences develop voluntary consumer behavior.

Although most studies on ethical consumers have focused on altruistic or ethical obligations or identity, our study demonstrated pride, which is known as a self-focused emotion that is different from others, pursuit of social status, and privilege [66], which plays an effective self-conscious moral emotion that drives self-actualization as a motivation for ethical consumption. Self-actualization also indicates a powerful motivation that drives CCB as compared to self-transcendence, which is known as a motivation for altruism.

Pride plays a vital role in promoting CCB as it has both a direct effect on CCB and an indirect effect via self-actualization on the ССВ based on the mediation effect analysis. When ethical consumption incorporates goal-driven behaviors with complicated decision-making based on time and energy-consuming information searches and trade-offs between different ethical behaviors [21], ethical consumers might feel pride in their ethical consumption. As green restaurant consumers need to undergo time-consuming problem-solving processes with great efforts to achieve their long-term value or life goal, such as ethical consumerism or environmentalism, with their own choice out of their own free will, they may feel pride in their achievement through green restaurant consumption. Ethical consumers may need to be appreciated and commended for their efforts and actual ethical purchases that everyone cannot undertake readily. Additionally, ethical consciousness does not necessarily drive ethical consumption; however, ethical consumers put such ethical consciousness and social responsibility into practice and this deserves to be taken pride in. Ethical consumption should not be taken for granted. Furthermore, their moral obligations and social responsibilities do not solve difficult problems related to ethical consumption. It is possible that ethical consumers have ethical elitism similar to compositional environmental elitism as "the accusation that the supporters of environmentalism are drawn primarily from the privileged or upper socioeconomic strata-that 
is, that environmentalists constitute a socioeconomic elite" [118] (p. 581). Some ethical consumers may take pride based on the elitism of ethical consumers, that is, being considered as privileged and intelligent social leaders. Further studies can address the different sources of ethical consumers' pride. With an emphasis on the co-existence of ethical consumers' altruistic and egoistic motivations and their complexity (e.g., $[27,28])$, further studies investigating various psychosocial motivations in ethical consumer research can provide interesting findings in the literature on ethical consumer behavior.

Our study found that both self-actualization as a self-oriented motivation and self-transcendence as an altruistic motivation led green restaurant consumption and advanced voluntary consumer behavior, CCB. Although many studies (e.g., [35,37,39]) have found that self-enhancement is negatively associated with an environmental disposition or behavior, and self-enhancement seems to be controversial in being considered as an ethical motivation, our study provides an empirical evidence of ethical consumers' psychological or value-driven egoistic, self-oriented, or self-conscious ethical motivations. Thus, self-actualization may be an appropriate self-oriented concept to understand ethical consumers' motivations. Moreover, the results of our study present that the path from pride via self-actualization to $C C B$ is stronger than the path from social healthy narcissism via self-transcendence to CCB.

Practically speaking, the self-actualization benefit rather than the emphasis on the altruistic benefit should be emphasized in social marketing to promote ethical consumption or marketing communications for green restaurants. As our result shows that the self-actualization leads self-transcendence, the marketing communications for ethical consumption including green restaurants should focus on simultaneity and the link between self-actualization and self-transcendence. People are concern with how to help others, however they may pay more attention to the self. Thus, marketing communications could focus on ethical consumers' pride and how ethical consumption can achieve self-actualization, and finally self-transcendence instead of the emphasis of others' benefits. As ethical consumers want to enjoy their pride and healthy social narcissism as a hubristic pride, marketing communications for green restaurant would promote their consumers' pride and healthy social narcissism. Green restaurants could be a community place for ethical consumers to cultivate profound environmental information and knowledge, and share their ethical consumption experiences with community programs. Green restaurateurs could satisfy ethical consumers' pride by emphasizing ethical consumers' efforts and extraordinariness and developing voluntary behaviors to improve ethical consumers' social identity. Thus, green restaurants have a special capacity to become a nest for the ethical consumer community.

Although this study makes contribution to the literature on green restaurant consumers, it has several limitations. This study may have a problem of common self-reporting bias that is common to a survey method. Although green restaurants are appropriate places to investigate $\mathrm{CCB}$, research in green restaurants that have strong interactions between service providers and consumers may have limited generalizability of the findings. We recommend that future studies should explore various service industries or products. As this study did not include other moral emotions, such as guilt, empathy, shame and embarrassment, further studies can provide more interesting findings from investigating these emotions. Cultural differences related to moral emotions and CCB may exist, and further studies can explore impacts of cultural differences.

Author Contributions: K.H., B.L. and J.H. developed conceptualization and methodology, K.H., B.L. and J.H. performed formal analysis, K.H. and J.H. performed writing-original draft preparation. All authors have read and agreed to the published version of the manuscript.

Funding: This research received no external funding.

Conflicts of Interest: The authors declare no conflict of interest. 


\section{References}

1. Green Restaurant Association. Green Restaurant Association 2017. Available online: http://www.dinegreen. $\mathrm{com} /$ (accessed on 28 October 2020).

2. Kim, M.J.; Hall, C.M. Can sustainable restaurant practices enhance customer loyalty? The roles of value theory and environmental concerns. J. Hosp. Tour. Manag. 2020, 43, 127-138. [CrossRef]

3. Baldwin, C.; Wilberforce, N.; Kapur, A. Restaurant and food service life cycle assessment and development of a sustainability standard. Int. J. Life Cycle Assess. 2011, 16, 40-49. [CrossRef]

4. Environmental Protection Agency. Ecological Structure Activity Relationships; EPA: Washington, DC, USA, 2009.

5. Stys, B. Green restaurants: Commercial kitchens face unique challenges as well as opportunities for saving energy and materials. Environ. Des. Construct. 2008, 11, 64.

6. Revell, A.; Blackburn, R. The business case for sustainability? An examination of small firms in the UK's construction and restaurant sectors. Bus Strategy Environ. 2007, 16, 404-420. [CrossRef]

7. David, S. Packaged Facts Research. 2014. Available online: http://www.packagedfacts.com/FutureFoodservice-Food-8472169/ (accessed on 28 October 2020).

8. Park, E.O.; Chae, B.K.; Kwon, J.; Kim, W.-H. The Effects of Green Restaurant Attributes on Customer Satisfaction Using the Structural Topic Model on Online Customer Reviews. Sustainability 2020, 12, 2843. [CrossRef]

9. Kuminoff, N.V.; Zhang, C.; Rudi, J. Are Travelers Willing to Pay a Premium to Stay at a "Green" Hotel? Evidence from an Internal Meta-Analysis of Hedonic Price Premia. Agric. Resour. Econ. Rev. 2010, 39, 468-484. [CrossRef]

10. Hu, H.-H.; Parsa, H.; Self, J. The Dynamics of Green Restaurant Patronage. Cornell Hosp. Q. 2010, 51, $344-362$. [CrossRef]

11. Jang, Y.J.; Kim, W.G.; Bonn, M.A. Generation Y consumers' selection attributes and behavioral intentions concerning green restaurants. Int. J. Hosp. Manag. 2011, 30, 803-811. [CrossRef]

12. Ham, S.; Han, H. Role of Perceived Fit with Hotels' Green Practices in the Formation of Customer Loyalty: Impact of Environmental Concerns. Asia Pac. J. Tour. Res. 2013, 18, 731-748. [CrossRef]

13. De Jong, A.; Varley, P. Foraging tourism: Critical moments in sustainable consumption. J. Sustain. Tour. 2018, 26, 685-701. [CrossRef]

14. Kim, Y.J.; Njite, D.; Hancer, M. Anticipated emotion in consumers' intentions to select eco-friendly restaurants: Augmenting the theory of planned behavior. Int. J. Hosp. Manag. 2013, 34, 255-262. [CrossRef]

15. Yu, Y.S.; Luo, M.; Zhu, D.H. The Effect of Quality Attributes on Visiting Consumers' Patronage Intentions of Green Restaurants. Sustainability 2018, 10, 1187. [CrossRef]

16. Liu, M.; Yu, Y.F. The Impact of Consumers' Beliefs on Attitudes and Patronage Intention toward Green Restaurant in Taiwan. Adv. Mater. Res. 2012, 524-527, 3501-3504. [CrossRef]

17. Teng, Y.-M.; Wu, K.-S. Sustainability Development in Hospitality: The Effect of Perceived Value on Customers' Green Restaurant Behavioral Intention. Sustainability 2019, 11, 1987. [CrossRef]

18. Kwok, L.; Huang, Y.-K.; Hu, L. Green attributes of restaurants: What really matters to consumers? Int. J. Hosp. Manag. 2016, 55, 107-117. [CrossRef]

19. Hwang, K.; Lee, B. Pride, mindfulness, public self-awareness, affective satisfaction, and customer citizenship behaviour among green restaurant customers. Int. J. Hosp. Manag. 2019, 83, 169-179. [CrossRef]

20. Golding, K.; Peattie, K. In search of a golden blend: Perspectives on the marketing of fair trade coffee. Sustain. Dev. 2005, 13, 154-165. [CrossRef]

21. Young, C.W.; Hwang, K.; McDonald, S.; Oates, C.J. Sustainable consumption: Green consumer behaviour when purchasing products. Sustain. Dev. 2010, 18, 20-31. [CrossRef]

22. Horberg, E.J.; Oveis, C.; Keltner, D. Emotions as Moral Amplifiers: An Appraisal Tendency Approach to the Influences of Distinct Emotions upon Moral Judgment. Emot. Rev. 2011, 3, 237-244. [CrossRef]

23. Williams, L.A.; DeSteno, D. Pride and perseverance: The motivational role of pride. J. Pers. Soc. Psychol. 2008, 94, 1007-1017. [CrossRef]

24. Sedikides, C.; Hart, C.M.; Cisek, S.Z.; Routledge, C. Finding meaning in the mirror: The existential pursuits of narcissists. In The Experience of Meaning in Life; Springer: Berlin/Heidelberg, Germany, 2013.

25. Aaker, J.L.; Williams, P. Empathy Versus Pride: The Influence of Emotional Appeals Across Cultures. J. Consum. Res. 1998, 25, 241-261. [CrossRef] 
26. Gebauer, J.E.; Sedikides, C.; Verplanken, B.; Maio, G.R. Communal narcissism. J. Pers. Soc. Psychol. 2012, 103, 854-878. [CrossRef] [PubMed]

27. Hwang, K.; Kim, H. Are Ethical Consumers Happy? Effects of Ethical Consumers' Motivations Based on Empathy Versus Self-orientation on Their Happiness. J. Bus. Ethics 2016, 151, 579-598. [CrossRef]

28. Green, T.; Peloza, J. Finding the Right Shade of Green: The Effect of Advertising Appeal Type on Environmentally Friendly Consumption. J. Advert. 2014, 43, 128-141. [CrossRef]

29. Carrigan, M.; Attalla, A. The myth of the ethical consumer-Do ethics matter in purchase behaviour? J. Consum. Mark. 2001, 18, 560-578. [CrossRef]

30. Auger, P.; DeVinney, T.M. Do What Consumers Say Matter? The Misalignment of Preferences with Unconstrained Ethical Intentions. J. Bus. Ethics 2007, 76, 361-383. [CrossRef]

31. Fowler, J.G. Customer citizenship behavior: An expanded theoretical understanding. Int. J. Bus. Soc. Sci. 2013, 4, 1-8.

32. Bayton, J.A. Motivation, Cognition, Learning: Basic Factors in Consumer Behavior. J. Mark. 1958, 22, $282-289$. [CrossRef]

33. Solomon, M.R.; Bamossy, G.; Askegaard, S. Consumer Behaviour: A European Perspective; Financial Times Prentice Hall: Harlow, ND, USA, 1999.

34. Arnocky, S.; Stroink, M.L.; Decicco, T. Self-construal predicts environmental concern, cooperation, and conservation. J. Environ. Psychol. 2007, 27, 255-264. [CrossRef]

35. Schultz, P.W.; Zelezny, L. Values as predictors of environmental attitudes: Evidence for consistency across 14 countries. J. Environ. Psychol. 1999, 19, 255-265. [CrossRef]

36. Schwartz, S.H.; Bilsky, W. Toward a universal psychological structure of human values. J. Pers. Soc. Psychol. 1987, 53, 550-562. [CrossRef]

37. Steenhaut, S.; Van Kenhove, P. An Empirical Investigation of the Relationships among a Consumer's Personal Values, Ethical Ideology and Ethical Beliefs. J. Bus. Ethics 2006, 64, 137-155. [CrossRef]

38. Schwartz, S.H. Universals in the Content and Structure of Values: Theoretical Advances and Empirical Tests in 20 Countries. Adv. Exp. Soc. Psychol. 1992, 25, 1-65. [CrossRef]

39. Pepper, M.; Jackson, T.; Uzzell, D. An examination of the values that motivate socially conscious and frugal consumer behaviours. Int. J. Consum. Stud. 2009, 33, 126-136. [CrossRef]

40. Ponizovskiy, V.; Grigoryan, L.; Kühnen, U.; Boehnke, K. Social Construction of the Value-Behavior Relation. Front. Psychol. 2019, 10, 1-12. [CrossRef] [PubMed]

41. Jaini, A.; Quoquab, F.; Mohammad, J.; Hussin, N. Antecedents of green purchase behavior of cosmetics products An empirical investigation among Malaysian consumers. Int. J. Ethics Syst. 2019, 36, 1-19.

42. Batson, C.D. Prosocial motivation: Is it ever truly altruistic? In Advances in Experimental Social Psychology; Berkowitz, L., Ed.; Academic: San Diego, CA, USA, 1987; Volume 20, pp. 65-122.

43. Batson, C.D. The Altruism Question. In Toward a Social-Psychological Answer; Erlbaum: Hillsdale, NJ, USA, 1991.

44. Takahashi, M.; Overton, W.F. Cultural Foundations of Wisdom: An Integrated Developmental Approach. In A Handbook of Wisdom: Psychological Perspectives; Cambridge University Press: Cambridge, UK, 2005; pp. 32-60.

45. Corsini, R.J.; Wedding, D. Current Psycholherapies; Peacock: ltasca, IL, USA, 1989.

46. Ivtzan, I.; Gardner, H.E.; Bernard, I.; Sekhon, M.; Hart, R. Wellbeing through self-fulfilment: Examining developmental aspects of self-actualization. Humanist. Psychol. 2013, 41, 119-132. [CrossRef]

47. Knapp, R.R. Handbook for the Personal Orientation Inventory; Edits: Washington, DC, USA, 1990.

48. Maslow, A.H. A theory of human motivation. Psychol. Rev. 1943, 50, 370-396. [CrossRef]

49. Homer, P.M.; Kahle, L.R. A structural equation test of the value-attitude-behavior hierarchy. J. Pers. Soc. Psychol. 1988, 54, 638-646. [CrossRef]

50. Fraj, E.; Martinez, E. Environmental values and lifestyles as determining factors of ecological consumer behaviour: An empirical analysis. J. Consum. Mark. 2006, 23, 133-144. [CrossRef]

51. Levenson, M.R.; Jennings, P.A.; Aldwin, C.M.; Shiraishi, R.W. Self-Transcendence: Conceptualization and Measurement. Int. J. Aging Hum. Dev. 2005, 60, 127-143. [CrossRef] [PubMed]

52. Koltko-Rivera, M.E. Rediscovering the later version of Maslow's hierarchy of needs: Self-transcendence and opportunities for theory, research, and unification. Rev. Gen. Psychol. 2006, 10, 302-317. [CrossRef] 
53. Le, T.N. Life Satisfaction, Openness Value, Self-Transcendence, and Wisdom. J. Happiness Stud. 2010, 12, 171-182. [CrossRef]

54. Beaumont, S.L. Identity Processing and Personal Wisdom: An Information-Oriented Identity Style Predicts Self-Actualization and Self-Transcendence. Identity Int. J. Theory Res. 2009, 9, 95-115. [CrossRef]

55. Kim, S.; Thibodeau, R.; Jorgensen, R.S. Shame, guilt, and depressive symptoms: A meta-analytic review. Psychol. Bull. 2011, 137, 68-96. [CrossRef]

56. Michie, S. Pride and Gratitude: How Positive Emotions Influence the Prosocial Behaviors of Organizational Leaders. J. Leadersh. Organ. Stud. 2009, 15, 393-403. [CrossRef]

57. McCullough, M.E.; Emmons, R.A.; Tsang, J. The grateful disposition: A conceptual and empirical topography. J Pers. Soc. Psychol. 2002, 82, 112-127. [CrossRef]

58. Mascolo, M.F.; Fischer, K.W. Developmental transformations in appraisals for pride, shame, and guilt. In Self-Conscious Emotions: The Psychology of Shame, Guilt, Mbarrassment, and Pride; Tangney, J.P., Fischer, K.W., Eds.; Guilford: New York, NY, USA, 1960; pp. 64-113.

59. Carver, C.S.; Sinclair, S.; Johnson, S.L. Authentic and hubristic pride: Differential relations to aspects of goal regulation, affect, and self-control. J. Res. Pers. 2010, 44, 698-703. [CrossRef]

60. Katzir, M.; Eyal, T.; Meiran, N.; Kessler, Y. Imagined positive emotions and inhibitory control: The differentiated effect of pride versus happiness. J. Exp. Psychol. Learn. Mem. Cogn. 2010, 36, 1314-1320. [CrossRef]

61. Dorfman, A.; Eyal, T.; Bereby-Meyer, Y. Proud to cooperate: The consideration of pride promotes cooperation in a social dilemma. J. Exp. Soc. Psychol. 2014, 55, 105-109. [CrossRef]

62. Shiota, M.N.; Keltner, D.; John, O.P. Positive emotion dispositions differentially associated with Big Five personality and attachment style. J. Posit. Psychol. 2006, 1, 61-71. [CrossRef]

63. Lindenberg, S.; Steg, L. Normative, Gain and Hedonic Goal Frames Guiding Environmental Behavior. J. Soc. Issues 2007, 63, 117-137. [CrossRef]

64. Tracy, J.L.; Robins, R.W. Conceptual and empirical strengths of the authentic/hubristic model of pride. Emotion 2014, 14, 33-37. [CrossRef]

65. Maslow, A. Motivation and Personality, 2nd ed.; Harper and Row: New York, NY, USA, 1970.

66. Tracy, J.L.; Cheng, J.T.; Robins, R.W.; Trzesniewski, K.H. Authentic and Hubristic Pride: The Affective Core of Self-esteem and Narcissism. Self-Identity 2009, 8, 196-213. [CrossRef]

67. Twenge, J.M.; Campbell, W.K. Increases in positive self-views among high school students: Birth-cohort changes in anticipated performance, self-satisfaction, self-liking, and self-competence. Psychol. Sci. 2008, 19, 1082-1086. [CrossRef] [PubMed]

68. Baumeister, R.F.; Vohs, K.D. Narcissism as addiction to esteem. Psychol. Inq. 2001, 12, 206-210.

69. Rhodewalt, F.; Morf, C.C. On self-aggrandizement and anger: A temporal analysis of narcissism and affective reactions to success and failure. J. Pers. Soc. Psychol. 1998, 74, 672-685. [CrossRef]

70. Baumeister, R.F.; Campbell, J.D.; Krueger, J.I.; Vohs, K.D. Does High Self-Esteem Cause Better Performance, Interpersonal Success, Happiness, or Healthier Lifestyles? Psychol. Sci. Public interest 2003, 4, 1-44. [CrossRef]

71. Wink, P.; Dillon, M.; Fay, K. Spiritual Seeking, Narcissism, and Psychotherapy: How Are They Related? J. Sci. Study Relig. 2005, 44, 143-158. [CrossRef]

72. Sovine, D.L. Disorders of narcissism: Diagnostic, clinical, and empirical implications. J. Psychother. Pract. Res. 1999, 8, 174.

73. Sedikides, C.; Rudich, E.A.; Gregg, A.P.; Kumashiro, M.; Rusbult, C. Are normal narcissists psychologically healthy?: Self-esteem matters. J. Pers. Soc. Psychol. 2004, 87, 400-416. [CrossRef] [PubMed]

74. Rose, P. The happy and unhappy faces of narcissism. Pers. Individ. Differ. 2002, 33, 379-391. [CrossRef]

75. Watson, P.J.; Morris, R.J. Narcissism, empathy and social desirability. Pers. Individ. Differ. 1991, 12, 575-579. [CrossRef]

76. Edelstein, R.S.; Newton, N.J.; Stewart, A.J. Narcissism in midlife: Longitudinal changes in and correlates of women's narcissistic personality traits. J. Pers. 2012, 80, 1179-1204. [CrossRef]

77. Ackerman, R.A.; Witt, E.A.; Donnellan, M.B.; Trzesniewski, K.H.; Robins, R.W.; Kashy, D. What Does the Narcissistic Personality Inventory Really Measure? Assessment 2011, 18, 67-87. [CrossRef]

78. Żemojtel-Piotrowska, M.; Piotrowski, J.P.; Maltby, J. Agentic and communal narcissism and satisfaction with life: The mediating role of psychological entitlement and self-esteem. Int. J. Psychol. 2015, 52, 420-424. [CrossRef] 
79. Maslow, A.H. The farther reaches of human nature. J Transpers. Psychol. 1969, 1, 1-9.

80. Reischer, H.N.; Roth, L.J.; Villarreal, J.A.; McAdams, D.P. Self-transcendence and life stories of humanistic growth among late-midlife adults. J. Person. 2020, 1-20. [CrossRef]

81. Sinha, I.J.; DeSarbo, W.S. An integrated approach toward the spatial modeling of perceived customer value. J. Mark. Res. 1998, 25, 236-249. [CrossRef]

82. Sweeney, J.C.; Soutar, G.N.; Johnson, L.W. The role of perceived risk in the quality-value relationship: A study in a retail environment. J. Retail. 1999, 75, 77-105. [CrossRef]

83. Gardial, S.F.; Flint, D.J.; Woodruff, R.B. Trigger events: Exploring the relationships between critical events and consumers' evaluations, standards, emotions, values and behavior. J. Consum. Satisf. Dissatisf. Complain. Behav. 1996, 9, 35-51.

84. Woodruff, R.B. Customer value: The next source for competitive advantage. J. Acad. Mark. Sci. 1997, 25, 139-153. [CrossRef]

85. Zeithaml, V.A. Consumer perceptions of price, quality, and value: A means-end model and synthesis of evidence. J. Mark. 1988, 52, 2-22. [CrossRef]

86. Sheth, J.N.; Newman, B.I.; Gross, B.L. Why we buy what we buy: A theory of consumption values. J. Bus. Res. 1991, 22, 159-170. [CrossRef]

87. Narasimhan, K. Services Marketing: Integrating Customer Focus Across the Firm. Manag. Serv. Qual. Int. J. 2004, 14, 436-437. [CrossRef]

88. Westbrook, R.A.; Reilly, M.D. Value-percept disparity: An alternative to the disconfirmation of expectations theory of consumer satisfaction. ACR N. Am. Adv. 1983, 10, 256-261.

89. Zhang, J.; Bloemer, J.M.M. The Impact of Value Congruence on Consumer-Service Brand Relationships. J. Serv. Res. 2008, 11, 161-178. [CrossRef]

90. Bettencourt, L. Customer voluntary performance: Customers as partners in service delivery. J. Retail. 1997, 73, 383-406. [CrossRef]

91. Anaza, N.A. Personality Antecedents of Customer Citizenship Behaviors in Online Shopping Situations. Psychol. Mark. 2014, 31, 251-263. [CrossRef]

92. Groth, M. Customers as Good Soldiers: Examining Citizenship Behaviors in Internet Service Deliveries. J. Manag. 2005, 31, 7-27. [CrossRef]

93. Yi, Y.; Gong, T.; Lee, H. The Impact of Other Customers on Customer Citizenship Behavior. Psychol. Mark. 2013, 30, 341-356. [CrossRef]

94. Oliva, R.; Sterman, J. Cutting Corners and Working Overtime: Quality Erosion in the Service Industry. Manag. Sci. 2001, 47, 894-914. [CrossRef]

95. Yi, Y.; Gong, T. Customer value co-creation behavior: Scale development and validation. J. Bus. Res. 2013, 66, 1279-1284. [CrossRef]

96. Yi, Y.; Nataraajan, R.; Gong, T. Customer participation and citizenship behavioral influences on employee performance, satisfaction, commitment, and turnover intention. J. Bus. Res. 2011, 64, 87-95. [CrossRef]

97. Rihova, I.; Buhalis, D.; Moital, M.; Gouthro, M.-B. Conceptualising Customer-to-customer Value Co-creation in Tourism. Int. J. Tour. Res. 2014, 17, 356-363. [CrossRef]

98. Jöreskog, K.G.; Sörbom, D. Lisrel 8: Structural Equation Modeling with the Simplis Command Language; Erlbaum: Hillsdale, NJ, USA, 1993.

99. Arbuckle, J.L. AMOS (Version 7.0); SPSS: Chicago, IL, USA, 2006.

100. Hair, J.F.; Black, W.C.; Babin, B.J.; Anderson, R.E.; Tatham, R.L. Multivariate Data Analysis, 7th ed.; Pearson Prentice-Hall: Upper Saddle River, NJ, USA, 2010.

101. Browne, M.W.; Cudeck, R. Alternative Ways of Assessing Model Fit. In Testing Structural Equation Models; Bollen, K.A., Long, J.S., Eds.; Sage: Newbury Park, CA, USA, 1993; pp. 136-162.

102. Kim, J.-E.; Johnson, K.K.P. The Impact of Moral Emotions on Cause-Related Marketing Campaigns: A Cross-Cultural Examination. J. Bus. Ethics 2013, 112, 79-90. [CrossRef]

103. Ames, D.R.; Rose, P.; Anderson, C.P. The NPI-16 as a short measure of narcissism. J. Res. Pers. 2006, 40, 440-450. [CrossRef]

104. Raskin, R.; Terry, H. A principal-components analysis of the Narcissistic Personality Inventory and further evidence of its construct validity. J. Pers. Soc. Psychol. 1988, 54, 890-902. [CrossRef] 
105. Lau, M.A.; Bishop, S.R.; Segal, Z.V.; Buis, T.; Anderson, N.D.; Carlson, L.; Shapiro, S.; Carmody, J.; Abbey, S.; Devins, G. The toronto mindfulness scale: Development and validation. J. Clin. Psychol. 2006, 62, 1445-1467. [CrossRef]

106. Phang, C.; Sutanto, J.; Kankanhalli, A.; Li, Y.; Tan, B.; Teo, H.-H. Senior Citizens' Acceptance of Information Systems: A Study in the Context of e-Government Services. IEEE Trans. Eng. Manag. 2006, 53, 555-569. [CrossRef]

107. Nordlund, A.M.; Garvill, J. Effects of values, problem awareness, and personal norm on willingness to reduce personal car use. J. Environ. Psychol. 2003, 23, 339-347. [CrossRef]

108. Lam, L.W.; Chan, K.W.; Fong, D.; Lo, F. Does the look matter? The impact of casino Service scape on gaming customer satisfaction, intention to revisit, and desire to stay. Int. J. Hosp. Manag. 2011, 30, 558-567.

109. Seiders, K.; Voss, G.B.; Grewal, D.; Godfrey, A.L. Do Satisfied Customers Buy More? Examining Moderating Influences in a Retailing Context. J. Mark. 2005, 69, 26-43. [CrossRef]

110. Anderson, J.C.; Gerbing, D.W. Structural equation modelling in practice: A review and recommended two-step approach. Psychol. Bull. 1988, 103, 411-423. [CrossRef]

111. Hundleby, J.D.; Nunnally, J. Psychometric Theory. Am. Educ. Res. J. 1968, 5, 431. [CrossRef]

112. Fornell, C.; Larcker, D.F. Structural Equation Models with Unobservable Variables and Measurement Error: Algebra and Statistics. J. Mark. Res. 1981, 18, 382. [CrossRef]

113. Podsakoff, P.M.; MacKenzie, S.B.; Lee, J.Y.; Podsakoff, N.P. Common method biases in behavioral research: A critical review of the literature and recommended remedies. J. Appl. Psychol. 2003, 88, 879-953. [CrossRef]

114. Preacher, K.J.; Hayes, A.F. SPSS and SAS procedures for estimating indirect effects in simple mediation models. Behav. Res. Methods Instrum. Comput. 2004, 36, 717-731. [CrossRef]

115. Jackson, D.L. Revisiting Sample Size and Number of Parameter Estimates: Some Support for the N:q Hypothesis. Struct. Equ. Model. 2003, 10, 128-141. [CrossRef]

116. Doornik, J.A.; Hansen, H. An Omnibus Test for Univariate and Multivariate Normality. Oxf. Bull. Econ. Stat. 2008, 70, 927-939. [CrossRef]

117. Wiklund, J.; Yu, W.; Tucker, R.; Marino, L.D. ADHD, impulsivity and entrepreneurship. J. Bus. Ventur. 2017, 32, 627-656. [CrossRef]

118. Morrison, D.E.; Dunlap, R.E. Environmentalism and elitism: A conceptual and empirical analysis. Environ. Manag. 1986, 10, 581-589. [CrossRef]

Publisher's Note: MDPI stays neutral with regard to jurisdictional claims in published maps and institutional affiliations.

(C) 2020 by the authors. Licensee MDPI, Basel, Switzerland. This article is an open access article distributed under the terms and conditions of the Creative Commons Attribution (CC BY) license (http://creativecommons.org/licenses/by/4.0/). 